\title{
Calcareous nannofossils- and ammonites-based biostratigraphy of the Baghamshah Formation (Central Iran Basin, Iran)
}

\author{
Mădălina-Elena Kallanxhi ${ }^{*}$, Mostafa Falahatgar², Mojtaba Javidan ${ }^{3}$, \\ Mehdi Sarfi ${ }^{4} \&$ Tahere Parvizi ${ }^{5}$
}

\author{
${ }^{1}$ Babeş-Bolyai University, Department of Geology, Kogălniceanu 1, 400084 Cluj-Napoca, Romania \\ ${ }^{2}$ Sari Agricultural and Natural Resources University, Department of Irrigation, Khazar Boulevard, Sari, Iran \\ ${ }^{3}$ Islamic Azad University, Department of Geology, Shahrood Branch, Shahrood, Iran \\ ${ }^{4}$ Damghan University, School of Earth Sciences, Damghan 36716-41167, Iran \\ ${ }^{5}$ Isfahan University, Department of Geology, Isfahan, Iran
}

Received: January 2016; accepted March 2016

Available online 29 March 2016

DOI: http://dx.doi.org/10.5038/1937-8602.60.1.1288

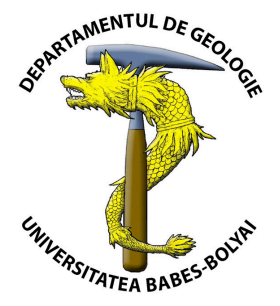

\begin{abstract}
Middle Jurassic calcareous nannofossils and ammonite assemblages from the Baghamshah Formation are described here, cropping out east of Semnan locality (Central Iran Basin, Iran). Low diversity and abundance characterize the nannofossil assemblages, which are dominated by genera belonging to the Family Watznaueriaceae. The calcareous nannofossil assemblages lack the usual markers for the Callovian interval, making difficult the age attribution. Ammonite assemblages display low diversity and poor preservation. From a biostratigraphical point of view, nannofossil assemblages would suggest that the material studied belongs to the NJT12 Zone from the Tethyan / sub-Mediterranean province and to the NJ12b subzone - lower NJ13 Zone from the Boreal province, correlating to the ammonite Tethyan / sub-Mediterranean Gracilis Zone and to the Boreal / sub-Boreal Koenigi - Calloviense Zones, yielding a Lower Callovian biostratigraphical distribution.
\end{abstract}

Keywords: Middle Jurassic, Lower Callovian, Central Iran Basin, calcareous nannofossils, ammonites, biostratigraphy.

\section{INTRODUCTION}

The Jurassic biostratigraphy is mainly based on ammonites, but the calibration of the Jurassic successions from different paleogeographical areas, using ammonite assemblages, depends on their preservation, provincialism, abundance and discontinuous distribution. The variations in ammonites abundance and distribution from area to area resulted into the separation of two main realms in Europe, namely the Boreal and the Tethys provinces (Arkell, 1956; Cariou, 1973). This separation is supported also by calcareous nannofossil evidences.

Calcareous nannofossils represent an important and useful tool in biostratigraphical dating of the Lower - Middle Jurassic marine sediments, due to their rapid evolution and the continuity of bioevents during this time interval. During the last decades, the studies dealing with Jurassic calcareous nannofossil biostratigraphy are based on data collected from different sections from the Boreal Realm / northern Europe, including Germany, England and northern France (Young et al., 1986; Bown, 1987a, b, 1996; Bown and Cooper, 1989), from the Tethyan / Sub-Mediterranean Province, mainly Portugal, Morocco and Switzerland (de Kaenel and Bergen, 1993; de Kaenel et al., 1996) and from the northern and central Italy and southern France of the Tethyan / Mediterranean Province
(Baldanza et al., 1990; Cobianchi, 1990, 1992; Erba, 1990; Lozar, 1992; Reale et al., 1992; Mattioli, 1993, 1994, 1995; Bucefalo Palliani and Mattioli, 1994; Sciunnach and Erba, 1994; Bartolini et al., 1995; Mattioli and Erba, 1999). There are some recent studies which focus on the Lower Jurassic nannofossils from the Northern Spain (Iberian Peninsula), the corridor between the Boreal and Tethyan Domains (Perilli et al., 2010; Mattioli et al., 2013; Fraguas et al., 2015, 2016).

Several zonations for Lower - Middle Jurassic time interval were proposed for the above mentioned paleogeographical areas.

The Central Iran Basin (Fig. 1) represents an important structural unit of the Iran Plate. The paleogeographical position of the Iran Plate (Fig. 2) during the Middle Late Jurassic (central and northern Iran) was along at the southern margin of Eurasia (Enay et al., 1993; Thierry, 2000; Seyed-Emami et al., 2008). No studies of calcareous nannofossils are known from the Middle Jurassic sediments of the Central Iran Basin (Iran). The biostratigraphy of the Middle Jurassic Baghamshah Formation (Iran) was previously established based on ammonites (Alavi-Naini, 1972; SeyedEmami et al., 1997, 1998, 2002). An age ranging from ?Middle - Late Bathonian to Early Callovian was established (Seyed-Emami et al., 1997, 1998), reaching up into the Middle Callovian in some areas (Seyed-Emami et al., 2002). 

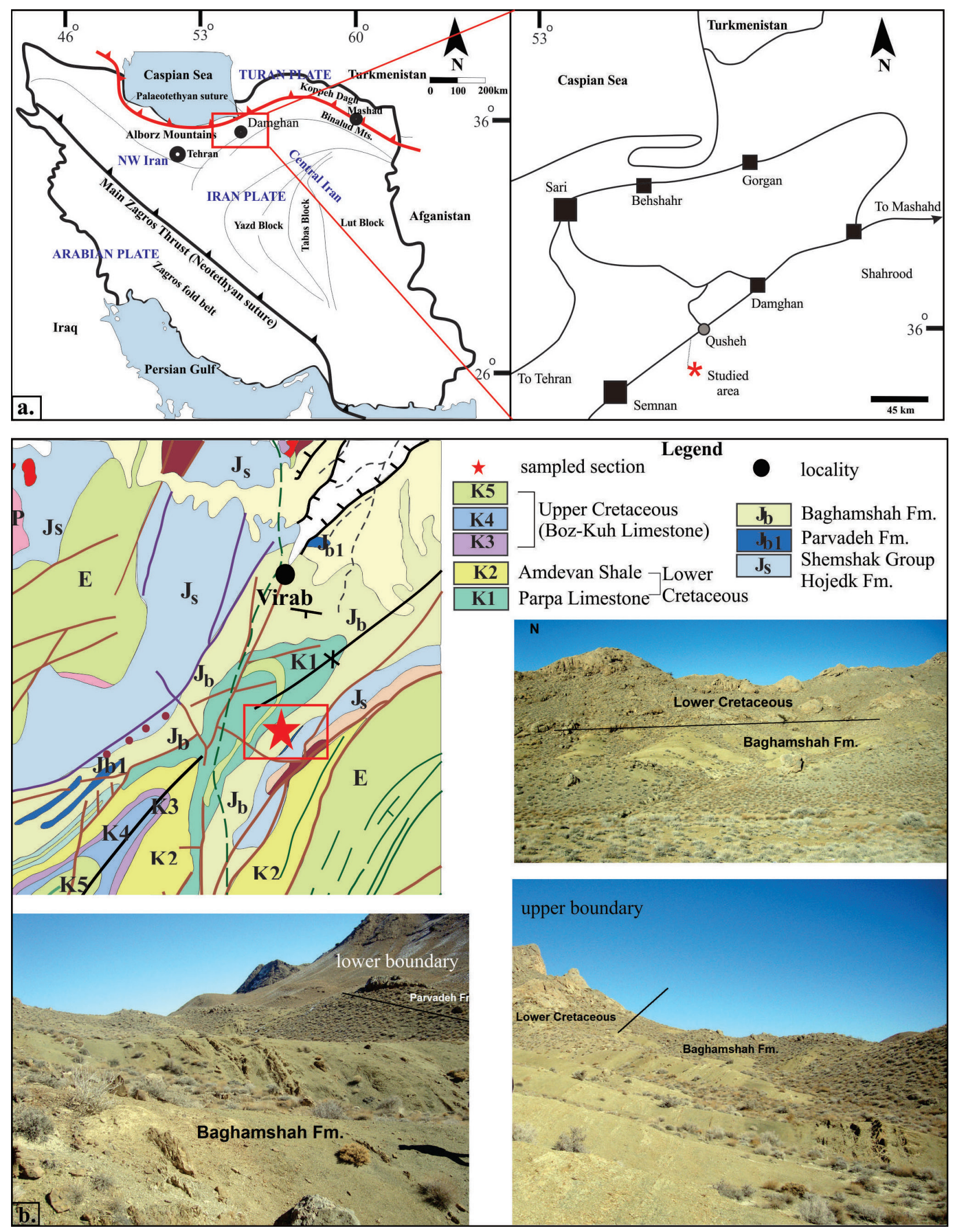

Fig. 1. a) General map of Iran including main tectonic units and the location of the studied area; b) Geological map of the area (1:100 000, redrawn after Geological Survey of Iran) and detailed pictures showing the lower contact with the Parvadeh Fm. and the upper contact with the Lower Cretaceous deposits, belonging to the Parpa Fm.

Palynomorphs from the Baghamshah Formation sediments were studied by Hashemi-Yazdi et al. (2015).

The aim of this study is to bring new contributions to the biostratigraphy of the Baghamshah Formation, based on calcareous nannofossil and ammonite assemblages.

\section{GEOLOGICAL SETTINGS}

The Baghamshah Formation was first described by Stöcklin (1961) and Stöcklin et al. (1965) in the eastern part of Tabas city, in central Iran. At the type section, the 


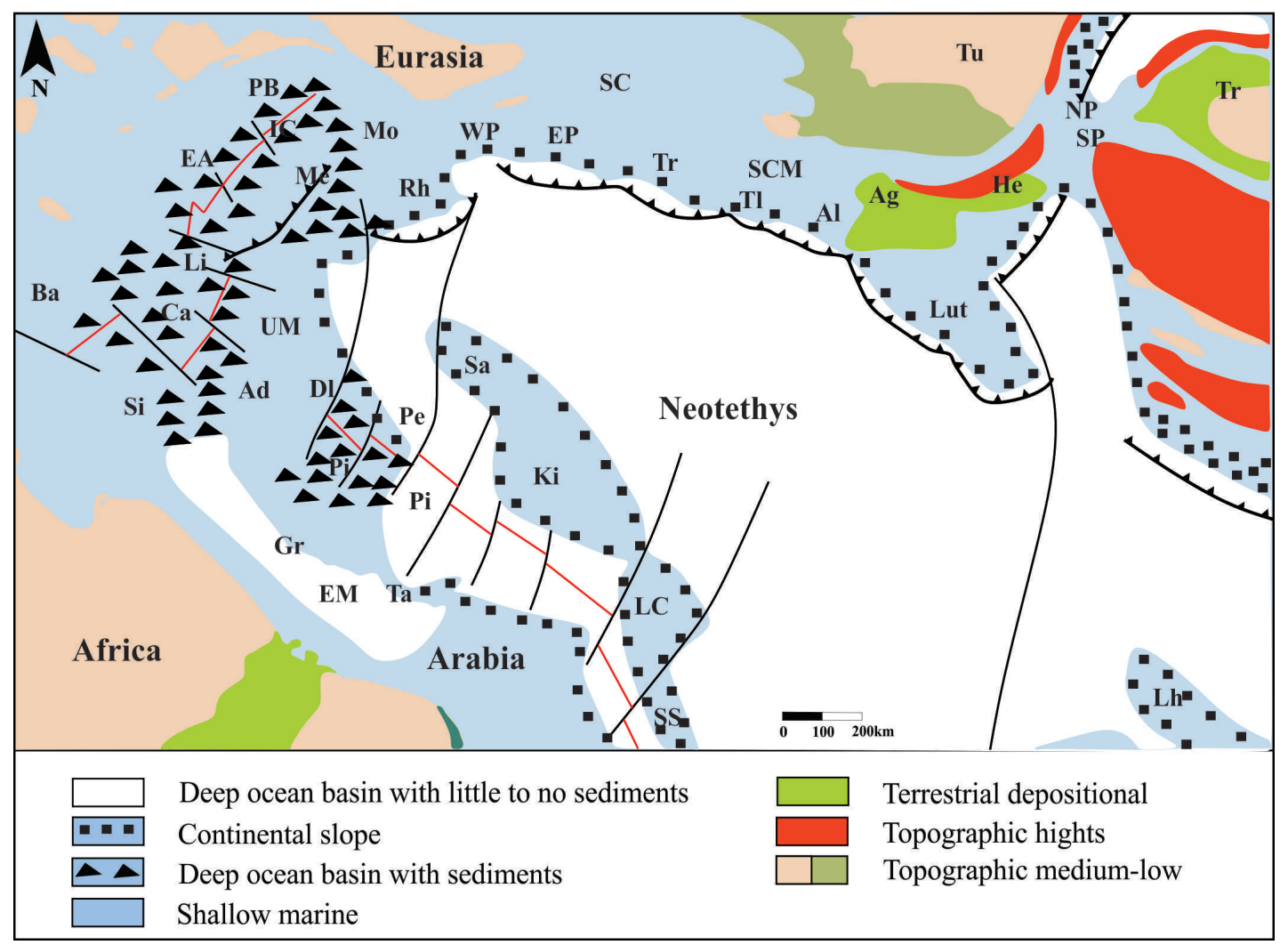

Fig. 2. Paleogeographical map of the southern margin of Eurasia during Middle Jurassic (simplified from Golonka, 2004). Abbreviations: Ad - Adria (Apulia), Ag - Aghdarband (southern Kopet Dagh), Al - Alborz, Ba - Balearic, Ca-Calabria - Campania, Di - Dinarides, EA - Eastern Alps, EM - Eastern Mediterranean, EP - Eastern Pontides, Gr - Greece, He - Herat, IC - Inner Carpathians, Ki - Kirsehir, LC - Lesser Caucasus, Lh - Lhasa, Li - Ligurian (Piemont), .Lut -Lut, Me-Meliata, Mo-Moesia, NP-North Pamir, PB-Pieniny Klippen Belt Ocean, Pe-Pelagonian plate, Pi - Pindos Ocean, Rh - Rhodopes, Sa - Sakarya, SC - Scythian, SCM - South Caspian Microcontinent, Si - Sicily, SP - South Pamir, SS - Sanandaj-Sirjan, Ta - Taurus terrain, Tl - Talysh, Tr - Transcaucasus, Tu - Turan, UM - Umbria-Marche, WP - Western Pontides.

formation is $496 \mathrm{~m}$ thick and consists mainly of yellowish to greenish marls, with alternations of sandstones, siltstones, shales and a few gypsums layers. At the type section, the Baghamshah sediments are conformably underlying by the Parvadeh Formation and conformably overlaid by the Late Jurassic Esfandiar Formation. In the most regions of central Iran, the upper boundary of the Baghamshah Formation is conformable, but in northern and central Kalmard area (Central Iran Basin) there are some marks of disconformities, such as bioturbation and oxidation characteristics (Aghanabati, 1975).

The Baghamshah Formation is the second formation of the Magu group (comprising an interval from Upper Bajocian -Upper Jurassic), described for the first time by Aghanabati (1975) for the second cycle of the Jurassic successions of Central Iran Basin. The sedimentary sequence comprises marine deposits ranging from Middle Bathonian to Late Jurassic interval. The Baghamshah Fomation is comparable with the upper part of the Dalichai Formation in the Alborz Mountains. In Central Iran Basin, this formation has several outcrops with various thicknesses.

The studied section is located in the Virab area, in the eastern part of Semnan locality (N $35^{\circ} 47^{\prime} 31^{\prime \prime}$, E $53^{\circ} 58^{\prime} 8^{\prime \prime}$ ), about $55 \mathrm{~km}$ west of Damghan, northern Iran (Fig. 1). In this region the Baghamshah Formation is about $48 \mathrm{~m}$ thick. These deposits overlie the limestones of the Parvadeh Formation conformably and are disconformably overlaid by the Lower
Cretaceous sediments. The sedimentary succession consists of four rock units, which, from the bottom to the top, are as follows (Fig. 3):

- Unit 1 consists of about $13 \mathrm{~m}$ greenish thin bedded shales alternating with thin bedded limestones;

- Unit 2 is composed of about $2 \mathrm{~m}$ dark medium bedded limestone with ammonites;

- Unit 3 is recognized by about $25 \mathrm{~m}$ greenish thin bedded shales alternating with thin bedded limestones with brachiopods, belemnite fragments and ammonites;

- Unit 4 includes $8 \mathrm{~m}$ greenish thin bedded shales alternating with sandy limestones.

\section{MATERIAL AND METHODS}

Ten samples for calcareous nannofossils, collected from the greenish shales at several different stratigraphic positions (Fig. 3), were prepared using the standard smear slide technique (Bown and Young, 1998) and investigated under the light microscope Leica DM 2700P (1000x magnification), in parallel light and crossed nicols. Semiquantitative analysis was performed by counting between 30 and 100 specimens per sample. A complete counting was not possible due to the very rare presence of calcareous nannofossils. The nannofossils individual abundance per sample (adopted after Concheryo and Wise, 2001, slightly modified) as presented in Fig. 3, was considered as follows: 


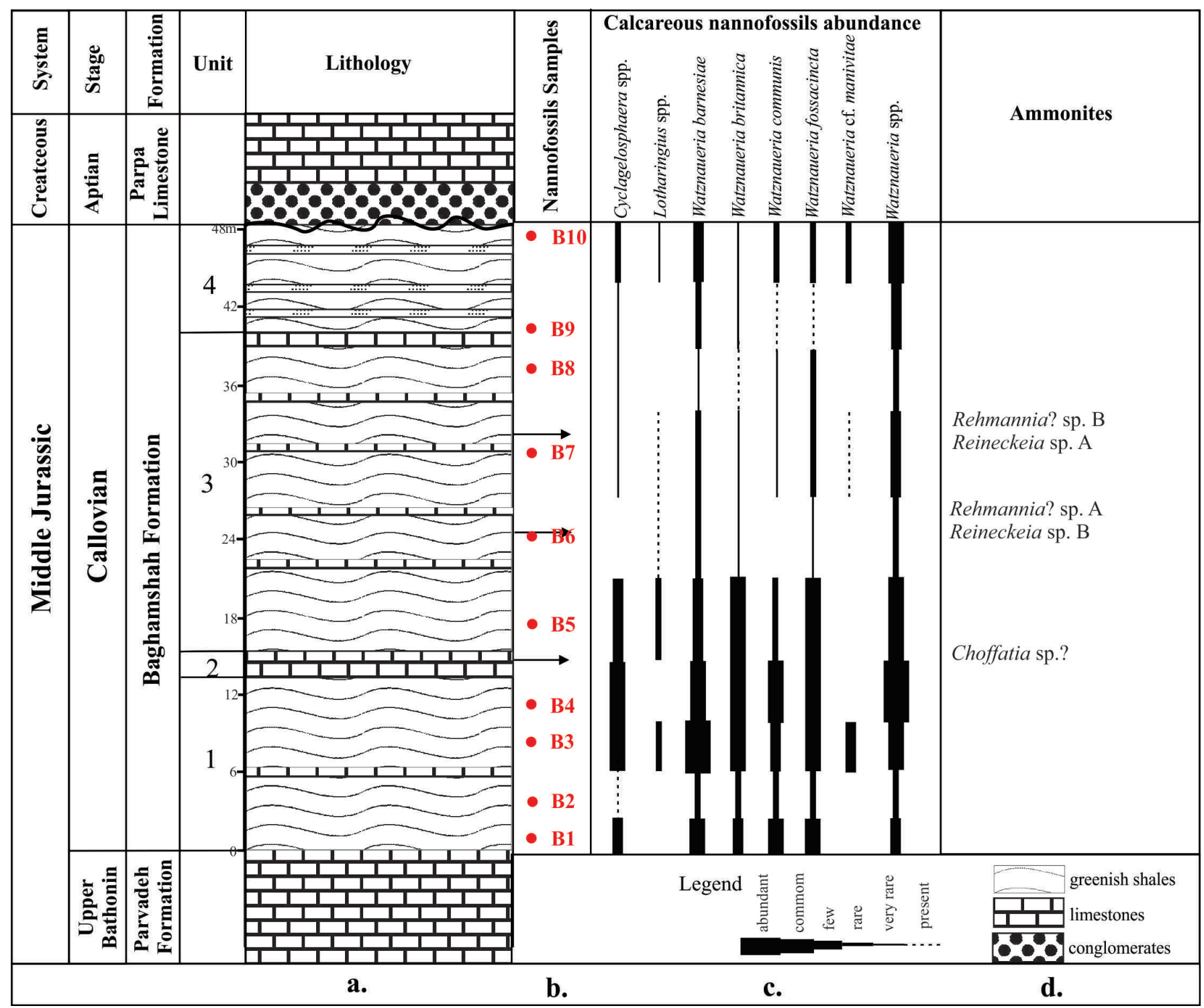

Fig. 3. a) Lithology of the investigated outcrop; b) Location of the collected nannofossil samples along the outcrop; c) Individual abundance patterns of most important calcareous nannofossil species and taxonomical groups; d) Location of the collected ammonite samples along the outcrop.

A - abundant (1 specimen / FOV - field of view), C - common (1 specimen / 2 - 10 FOV), F - few (1 specimen / $11-20$ FOV), R - rare (1 specimen / 21 - 50 FOV), VR - very rare (1 specimen / 50 - $100 \mathrm{FOV}), \mathrm{P}$ - present (1 specimen in more than $100 \mathrm{FOV}$ or per sample). Additionally, $300 \mathrm{FOV}$ were investigated for rarer taxa. Qualitative observations were performed by assessing the nannofossils preservation (Roth and Thierstein, 1972) as: M - moderate (dissolution and overgrowth are present; about $25 \%$ of the specimens cannot be identified at species level) and $\mathrm{P}$ - poor (the majority of the specimens cannot be identified at species level due to occurrence of dissolution, fragmentation, and/or overgrowth). The nannofossils pictures were captured under cross-polarized light (XPL), bright field (BF) and with gypsum plate (GP) with a Leica MC170 HD camera. The nannofossil zonations are based on the FO (First Occurrence) and LO (Last Occurrence) of the marker species.

Several ammonites were collected from Units 2 and 3 of the studied outcrop (Fig. 3). Due to the poor preservation their identification was only possible at the genus level.
The standard ammonites zones (AZ) for the sub-Boreal and Tethys / sub-Mediterranean provinces are used as in Callomon (2003). Correlation of the calcareous nannofossil zonations is based on de Kaenel and Bergen (1993) and de Kaenel et al. (1996) for the Tethyan / sub-Mediterranean Province and on Bown and Cooper (1998) for the Boreal Province.

\section{RESULTS}

\section{Calcareous nannofossil assemblage}

The calcareous nannofossil assemblages (Plate I) contain moderate to poorly preserved specimens, with very low diversity and abundance. A total number of 18 calcareous nannofossils (see Appendix 1 for taxonomical description) were identified, from which the autochthonous are only 11 species, whereas 7 species represent contamination material from Cretaceous and Paleogene periods.

The assemblages are dominated by species belonging to the family Watznaueriaceae, which in alphabetical 
order are: Cyclagelosphaera spp., Lotharingius spp., Watznaueria barnesiae, $W$. britannica, W. communis, $W$. fossacincta, Watznaueria cf. manivitae, Watznaueria cf. ovata, Watznaueria spp. The contamination material from younger levels is represented by: Calculites obscurus, Coccolithus foraminis, C. pelagicus, Cribrosphaerella ehrenbergii, Discoaster sp., Reticulofenestra sp., Sphenolithus sp.

\section{Ammonite assemblage}

The ammonite assemblages collected from the limestone levels (Plate II) are poorly preserved, thus their identification was only possible at the genus level. The following genera were identified: Reineckeia, Rehmannia and Choffatia.

\section{DISCUSSIONS}

\section{Calcareous nannofossils}

Regarding the calcareous nannofossils biostratigraphy, the bigest problem encountered in the present study was related to the lack of nannofossil index species characteristic for the uppermost Late Bathonian - Callovian interval.

For the Tethyan / sub-Mediterranean domain, partial correlation of the calcareous nannofossil standard zonations to the ammonites ones, for the upper Late Bathonian Callovian stage (Fig. 4), was made by de Kaenel and Bergen (1993) and de Kaenel et al. (1996), while for the Boreal / sub-Boreal Province (NW Europe) the ammonite and nannofossil zonations are calibrated after Bown and Cooper (1998).

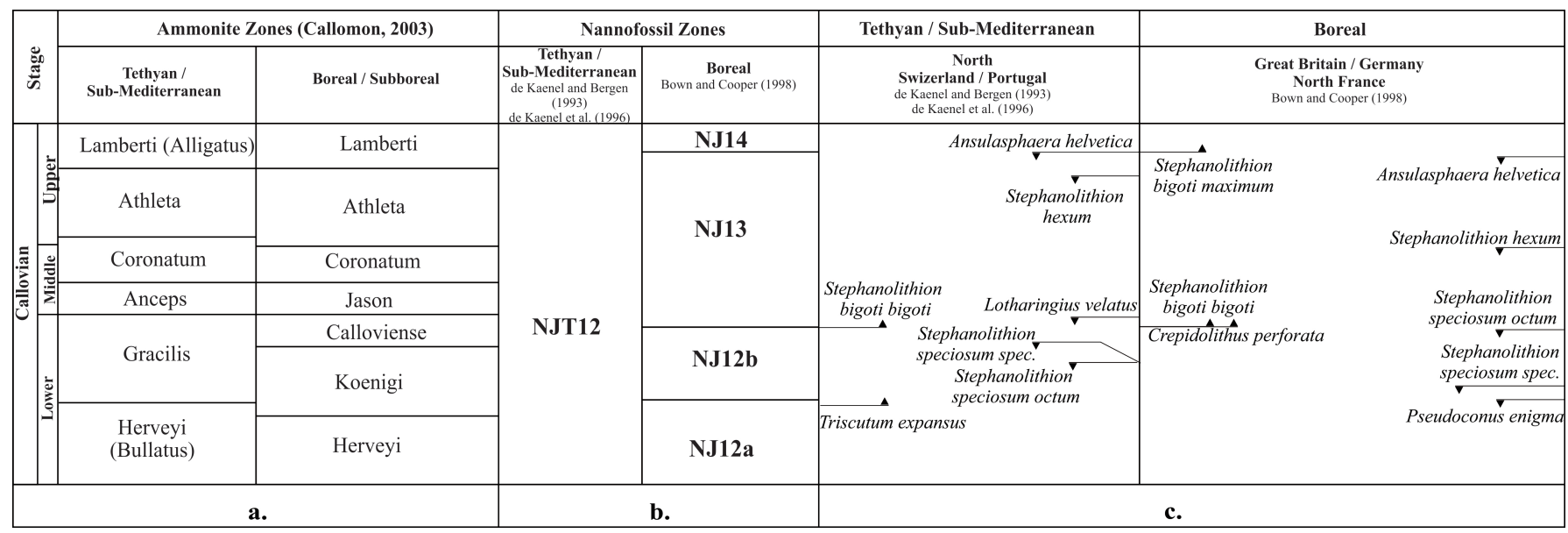

Fig. 4. Correlation of the standard ammonite and calcareous nannofossil biozonations: a -Ammonite zonation from Tethyan/sub-Mediterranean and sub-Boreal provinces (after Callomon, 2003); b - Nannofossil zonations for Tethyan / sub-Mediterranean areas (after de Kaenel and Bergen, 1993; de Kaenel et al., 1996) and Boreal province (after Bown and Cooper, 1998); c-Tethyan / sub-Mediterranean and Boreal / sub-Boreal combined calcareous nannofossils primary (zonal) and secondary events.

Within the Tethyan / sub-Mediterranean (Portugal, Morocco and northern Switzerland) province, the zonation proposed by de Kaenel et al. (1996) for the uppermost Bathonian - Callovian is based on the following nannofossil events, from base to the top: FO of Stephanolithion hexum, FO of Triscutum expansus, LO of Stephanolithion speciosum octum, LO of Stephanolithion speciosum speciosum, FO of Stephanolithion bigoti bigoti, LO of Lotharingius velatus, LO of Stephanolithion hexum and the LO of Ansulasphaera helvetica.

Correlation of the investigated material to the Boreal / sub-Boreal (Germany, Great Britain, northern France) calcareous nannofossil zones and subzones follows the concepts of Bown and Cooper (1998) and comprises the following standard zones and subzones: NJ12a - Stephanolithion hexum Subzone (from the FO of Ansulasphaera helvetica to the LO of Pseudoconus enigma), the NJ12b - Watznaueria manivitae Subzone (defined by the LO of Pseudoconus enigma at the base and the FO of Stephanolithion bigoti bigoti at the top) and the NJ13 - Stephanolithion bigotii bigotii Zone (defined FO of Stephanolithion bigoti bigoti at the base and at the top by the FO of Stephanolithion bigoti maximus).

Biostratigraphically, despite the difficulty created by the missing index species, probably the studied material belongs to long ranging NJT12 of de Kaenel et al. (1996) and to the NJ12b - lower NJ13 subzones of Bown and Cooper (1998), allowing the correlation with the sub-Mediterranean Gracilis Zone and with the Suboreal Koenigi - Caloviense Zones.

As already mentioned in the results chapter, the assemblages are dominated by the long-ranging taxa: Watznaueria barnesiae, W. fossacincta, W. britannica and W. communis, whose FO are always located in the lower stages of the Middle Jurassic. For a large amount of specimens, as shown in Fig. 3, due to the poor preservation, the identification was only possible at the genus level, and therefore they were all grouped under the Watznaueria spp. description (Pl. I, Figs. 5, 8). The identification of Cyclagelosphaera genus was difficult due to the deformation of the coccoliths, which might have been caused by the diagenesis processes. Nevertheless, it cannot be excluded that some of the specimens from the Watznaueria spp. group, actually belong to the Cyclagelosphaera genus.

The most abundant species is Watznaueria barnesiae (Pl. I, Figs. 1, 9-14, 24), which is present in all the analyzed samples. Its FO in the Boreal province is older (Rodd and Barnard, 1974) compared to the Tethyan area, where it is much younger and lies within the Bathonian (Erba, 1990; Mattioli, 1996; Mattioli and Erba, 1999).

The second in abundance, with continuous occurrence, is Watznaueria fossacincta (P1. I, Figs. 7, 21-23, 25), followed by Watznaueria britannica (Pl. I, Fig. 6, 20, 28, 29, 30, 31), and Watznaueria communis (Pl. I, Figs. 17, 18). 
Cyclagelosphaera spp. group shows a low abundance but a relatively continuous record. It is noticed in some samples (B3 and B4) the presence of Cyclagelosphaera cf. wiedmannii. Reale and Monechi (1994) described this species from several sections (from DSDP Site 534A in the NW Atlantic, Valdorbia section in Italy, Quissac section in SE France and Bihendula section from Somalia). They calibrated its FO at the base of the Callovian, within the Macrocephalus Zone, in the Quissac section (SE France). In the Mediterranean Domain (Italy and southern France), Mattioli and Erba (1999) found the FO of Cyclagelosphaera wiedmannii in the Upper Bathonian. Their biozonation for the Tethyan / Mediterranean Realm is not used in this study, due to the lack of marker species in the Mediterranean area, during the Callovian Stage. In the Boreal province, this species was not observed.

Lotharingius spp. group (P1. I, Figs. 2-4) display a low abundance in samples B3, B5, B6, B7, and B10. In sample B3 the presence of Lotharingius cf. velatus was noticed, a species whose LO is located at the top of the NJ12b Subzone of Bown and Cooper (1998), approximating the top of the Tethyan Gracilis and the sub-Boreal Calloviense ammonites zones.

The low diversity of nannofossils assemblages is comparable and shows certain similarities with those from recent studies (Rai and Garg, 2007; Jain, 2012) from the Early Callovian in the Kuldhar section (western Rajasthan, India).

The presence of the long-ranging Watznaueria genus in the investigated material, which dominates the Jurassic assemblages (Erba, 1990; Olivero, 2008), and the absence of more delicate marker genera, gives interesting information about the environmental conditions. The lack of other species may suggest that the diagenesis and dissolution processes were present and could have destroyed the most delicate species belonging to the Stephanolithion genus (Lozar, 1992, 1995; Mattioli, 1993, 1995, 1997).

The species Watznaueria barnesiae is considered by some authors as being one of the most dissolution-resistant taxa (Hill, 1975; Thierstein, 1980, 1981; Roth, 1981; Roth and Bowdler, 1981; Roth and Krumbach, 1986). Giraud (2009) suggests that the increase in abundance of $W$. barnesiae may be the result of the increase in diagenetic alteration. This species proliferates in oligotrophic marine environments (Roth and Krumbach, 1986; Premoli-Silva et al., 1989; Williams and Bralower, 1995; Burns and Bralower, 1998; Herrle, 2003; Erba and Tremolada, 2004), in shallow waters and restricted environments (Mutterlose, 1989). Its opportunistic behavior made it able to adapt to extreme marine conditions, characterizing low diversity assemblages (Thomsen, 1989; Mutterlose, 1991; Rai and Garg, 2007). Lees et al. (2004) suggest that blooms of Watznaueria barnesiae are related to high nutrient input which characterizes eutrophic environments. Roth (1983) describes bad preserved assemblages dominated by $W$. barnesiae from the Middle Callovian of the DSDP 534 A (Central Atlantic).

The paleoecological preferences of Watznaueria britannica, another important component of the studied material, are somehow connected to the size of the coccolith. Smaller morphotypes are suggested to prefer meso-eutrophic environments (Olivier et al., 2004; Giraud et al., 2006; Tremolada et al., 2006), while larger morphotypes are predominantly mesotrophic (Lees et al., 2004), and occupy areas characterized by more stable marine conditions (Giraud,
2009) to oligotrophic marine areas (Olivier et al., 2004; Giraud et al., 2006; Tremolada et al., 2006). Busson et al. (1992; 1993) consider W. britannica an eutrophic taxon.

Other species with discontinuous occurrence and low abundances are Watznaueria ovata (P1. I, Figs. 26, 27), which appears in 6 samples (B3, B5, B6, B7, B9, B10), and Watznaueria cf. manivitae (Pl. I, Figs. 15, 16, 19), in only 3 samples (B3, B7, B10).

\section{Ammonite assemblages biostratigraphy}

Previous studies on ammonites from other outcrops of the Baghamshah Formation, from the northern part of the Central Iran Basin (at the Djam area), were done by Alavi-Naini (1972), which described an assemblage consisting of Choffatia sp., Reineckeites sp., Brightia sp.and Bullatimorphites sp. Based on the above mentioned fauna, the author established the age of this formation as ranging from the Upper Bathonian to the Upper Callovian.

Seyed-Emami et al. (1997) studied the Baghamshah Formation from the NW Tabas, Central Iran and described for the first time Lower Callovian ammonites from this formation, such as cf. Pylloceras (Partschiceras), Paroxycerites subdiscus, Bullatimorphites (Kheraiceras) cosmopolitum, Macrocephalites cf. macrocephalus and Choffatia euryptycha. Seyed-Emami et al. (1998) described dimorphic pair of Cadomites for the first time from the lower Baghamshah Formation in the SW Tabas, central Iran.

The investigated ammonite assemblage contains poorly preserved specimens. Despite this, morphological features allowed the assignment of some specimens to various genera. The depressed whorl section with lateral tubercles at the end of short strong umbilical tubercles, (P1. II, Fig. 1) is typical features of the Lower Callovian Reineckeia. Conical lateral tubercles in the middle whorls, passing to bullae or lamellar periumbilical tubercles from which born flexuous ribs, characterize the Lower Callovian macroconch Rehmannia (Pl. II, Fig. 2). Also, specimens with compressed shell with no well developed tubercles (Pl. II, Figs. 4, 5) could belong to the same microconch Rehmannia.

The ammonites in the investigated outcrop belong to the Tethyan genera Reineckeia (P1. II, Figs. 1, 6-9), Rehmannia (P1. II, Figs. 2, 4, 5), and Choffatia (P1. II, Fig. 3), indicating the Lower Callovian, probably the Gracilis Zone. Several unidentified fragments were not included in the present interpretation.

\section{CONCLUSION}

Calcareous nannofossils assemblages were described for the first time from sediments collected from an outcrop of the Baghamshah Formation, located into the eastern part of Semnan city (Central Iran Basin, Iran). They are moderate to poorly preserved and low diverse. Additionally some few and poorly preserved ammonites from the same levels provide time-correlation with the standard scale.

From biostratigraphically point of view, the material correlates to the long ranging NJT12 Zone from the Tethyan / sub-Mediterranean province and to the NJ12b lower NJ13 Subzones from the Boreal Realm. The material is lacking the marker species of the Stephanolithion genus used to define the zonal boundaries and other index species 
such as Ansulasphaera helvetica, Triscutum expansus and Pseudoconus enigma as well. Correlation with the ammonite zonations indicates the Gracilis Zone of the Tethyan / sub-Mediterranean scale, and the Koenigi - Calloviense zones of the Boreal / sub-Boreal scale.

The most common species and taxonomic groups among the calcareous nannofossils are the long ranging species belonging to the genus Watznaueria, followed by the taxa Cyclagelosphaera spp. and Lotharingius spp.

As a general trend, based on the nannofossils identified, it can be suggested that the sediments were deposited under a warm and humid environment.

Acknowledgements. The authors thank Mr. Abbas Javidan for his support on field works and to Luminiţa Zaharia for the English corrections of the manuscript. The reviewers Ángela Fraguas and Horacio Parent are kindly thanked for their useful comments and suggestions, which significantly improved the quality of this manuscript.

\section{REFERENCES}

Aghanabati, S.A. 1975, Étude geologique de la region de Kalmard (W.Tabas) Iran Central. Stratigraphie et tectonique. Thesis, Grenoble, 231 p.

Alavi-Naini, M. 1972, Étude géologique de la region de Djam. Geological Survey of Iran, Report, 23:1-293.

Arkell, W.S. 1956, Standard of the European Jurassic. Bulletin of the Geological Society of America, Washington, 57: 1-34. http://dx.doi.org/10.1130/0016-7606(1946)57[1:SOTEJ]2.0.CO;2

Baldanza, A., Cresta, S. \& Mattioli, E. 1990, Bajocian Callovian Calcareous Nannofossils from Monte Nerone Area (Umbro-Marchean Apennine, Italy). Memorie descrittive della Carta Geologica d'Italia, 40: 225-236.

Bartolini, A., Baumgartner, P.O. \& Mattioli, E. 1995, Middle and Late Jurassic Radiolarian biostratigraphy of the Colle Bertone and Terminilletto sections (UmbriaMarche-Sabina Apennines, Central Italy): an integrated stratigraphical approach. In Middle Jurassic to Lower Cretaceous Radiolaria of Tethys: Occurences, sistematics, Biochronology (Baumgartner et al., Eds.), p. 817-831.

Bown, P.R. 1987a, The structural development of early Mesozoic coccoliths and its evolutionary and taxonomic significance. Abhandlungen der Geologischen Bundesanstalt Wien, 39: 33-49.

Bown, P.R. 1987b, Taxonomy, evolution, and biostratigraphy of Late Triassic-Early Jurassic calcareous nannofossils. Palaeontological Association, Special Papers in Palaeontology, 38: 118.

Bown, P.R. 1996, with contributions from the International Nannoplankton Association, Jurassic Working Group - Recent advances in Jurassic calcareous nannofossil research. GeoResearch Forum, 1-2: 55-66.

Bown, P.R., Cooper, M.K.E. 1989, New Calcareous nannofossil taxa from the Jurassic. Journal of Micropaleontology, 8 (1): 91-96. http://dx.doi.org/10.1144/jm.8.1.91

Bown, P.R., Cooper, M.K.E. 1998, Jurassic. In: Calcareous nannofossil biostratigraphy (Bown, P.R., Ed.). Kluwer Academic Publications, Dordrecht, p. 33-85. http://dx.doi.org/10.1007/978-94-011-4902-0_4
Bown, P.R., Young, J.R. 1998, Techniques. In: Calcareous nannofossil biostratigraphy (Bown, P.R., Ed.). Kluwer Academic Publications, Dordrecht, p. 16-28. http://dx.doi.org/10.1007/978-94-011-4902-0 2

Bucefalo Palliani, R., Mattioli, E. 1994, Enrichment in organic matter within the Early Toarcian marne di Monte Serrone Formation: a synchronous event in the Umbria-Marche Basin (Central Italy). Palaeopelagos, 4: 175-188.

Burns, C.E., Bralower, T.J. 1998, Upper Cretaceous nannofossil assemblages across the Western Interior Seaway: implications for the origins of lithologic cycles in the Greenhorn and Niobrara Formations. SEPM, Concepts in Sedimentology and Paleontology, 6: 35-58.

http://dx.doi.org/10.2110/csp.98.06.0035

Busson, G., Noël, D. \& Cornée, A. 1992, Les coccolithes en bboutons de manchetteQ et la genése des calcaires lithographiques du jurassique supérieur. Revue Paléobiology, 11: 255-271.

Busson, G., Noël, D., Contini, D., Mangin, A.-M., Cornée, A. \& Hantzpergue, P. 1993, Omniprésence de coccolithes dans des calcaires lagunaires du jurassique moyen et supérieur de france. Bulletin Du Centre De Recherches Elf Exploration Production, Elf-Aquitaine, 17: 291-301.

Callomon, J.H. 2003, The Middle Jurassic of western and northern Europe: its subdivisions, geochronology and correlations. Geological Survey of Denmark and Greenland Bulletin, 1: 61-73.

Cariou, E. 1973, Ammonites of the Callovien and Oxfordien. In Hallam, S. (Ed.). Atlas of Palaeogeography, p. 287-295.

Cobianchi, M.A. 1990, Biostratigrafia a nannofossili calcarei del pasaggio Domeriano-Toarciano in Val Navezze (Brescia). Atti Ticinensi di Scienze della Terra, 33: 19-25.

Cobianchi, M.A. 1992, Sinemuarian-Early Bajocian Calcareous Nannofossil Biostratigraphy of the Lombardy Basin (Southern Calcareous Alps; Northern Italy). Atti Ticinensi di Scienze della Terra, 35: 61-106.

Concheryo, A., Wise, S.W. Jr. 2001, Jurassic calcareous nannofossil from prerift sediments drilled during ODP Leg 173, Iberia Abyssal Plain, and their implications for rift tectonics. In: Proceedings of the Ocean Drilling Program, Scientific Results (Beslier, M.-O., Whitmarsh, R.B., Wallace, P.J. \& Girardeau, J. (Eds.), 173: 1-24.

de Kaenel, E., Bergen, J.A. 1993, New Early and Middle Jurassic coccolith taxa and biostratigraphy from the eastern proto-Atlantic (Marocco, Portug al and DSDP Site 547 B). Eclogue Geologica Helvetica, 86: 861-907.

de Kaenel, E., Bergen, J.A. \& von Salis Perch Nielsen, K. 1996, Jurassic calcareous nannofossil biostratigraphy of western Europe. Compilation of recent studies and calibration of bioevents. Bulletin de la Societe Geologique de France, 167: 15:28.

Enay, R., Guiraud, R, Ricou, L.E., Mangold, C., Thierry, J., Cariou, E., Bellion, Y. \& Dercourt, J. 1993, Callovian (162 to $158 \mathrm{Ma})$. In: Atlas Tethys Palaeoenvironmental Maps (Dercourt, J., Ricou, L. E. \& Vrielynck, B., Eds.). GauthierVillars, Paris, p. 81-95.

Erba, E. 1990, Calcareous nannofossil biostratigraphy of some Bajocian sections from Digne area (SE France). Memorie descrittive della Carta Geologica d'Italia, 40: 237-256. 
Erba, E., Tremolada, F. 2004, Nannofossil carbonate fluxes during the Early Cretaceous: phytoplankton response to nitrification episodes, atmospheric $\mathrm{CO}_{2}$, and anoxia, Paleoceanography, 19 (1): 1008. http://dx.doi.org/10.1029/2003pa000884

Fraguas Á., Comas-Rengifo, M.J. \& Perilli, N. 2015, Calcareous nannofossil biostratigraphy of the Lower Jurassic in the Cantabrian Range (Northern Spain). Newsletters on Stratigraphy, 48 (2): 179-199. http://dx.doi.org/10.1127/nos/2015/0059

Fraguas Á., 'Comas-Rengifo, M.J. \& Perilli, N. 2016, Erratum to "Calcareous nannofossil biostratigraphy of the Lower Jurassic in the Cantabrian Range (Northern Spain)". [Newsletter on Stratigraphy, 48/2 (2015), 179-199]. Newsletters on Stratigraphy, 49 (1): 69-70. http://dx.doi.org/10.1127/nos/2016/0070

Giraud, F. 2009, Calcareous nannofossil productivity and carbonate production across the Middle-Late Jurassic transition in the French Subalpine Basin. Geobios, 42: 699-714. http://dx.doi.org/10.1016/j.geobios.2009.05.002

Giraud, F., Pittet, B., Mattioli, E. \& Audouin, V. 2006, Paleoenvironmental controls on morphology and abundance of the coccolith Watznaueria britannica (Late Jurassic, southern Germany). Marine Micropaleontology, 60: 205-225. http://dx.doi.org/10.1016/j.marmicro.2006.04.004

Golonka, J. 2004, Plate tectonic evolution of the southern margin of Eurasia in the Mesozoic and Cenozoic. Tectonophysics, 381: 235-273. http://dx.doi.org/10.1016/j.tecto.2002.06.004

Hashemi-Yazdi, F., Sajjadi, F. \& Dehbozorgi, A. 2015, A new lycophyte miospore species from the Middle Jurassic of Iran. Revista Brasileira de Paleontologia. 18 (2): 251-260. http://dx.doi.org/10.4072/rbp.2015.2.06

Herrle, J.O. 2003, Reconstructing nutricline dynamics of midCretaceous oceans: evidence from calcareous nannofossils from the Niveau Paquier black shale (SE France). Marine Micropaleontology, 47 (3-4): 307-321. http://dx.doi.org/10.1016/s0377-8398(02)00133-0

Hill, M.E. 1975, Selective dissolution of mid-Cretaceous (Cenomanian) calcareous nannofossils. Micropaleontology, 21: 227-235. http://dx.doi.org/10.2307/1485025

Jain, S. 2012, Integrated biostratigraphy and palaeoenvironment of the Middle Jurassic sediments at Kuldhar (Jaisalmer), Western India. Journal of the Palaeontological Society of India, 57 (1): 1-41.

Lees, J.A., Bown, P.R., Young, J.R. \& Riding, J.B. 2004, Evidence for annual records of phytoplankton productivity in the Kimmeridge Clay Formation coccolith stone bands (Upper Jurassic, Dorset, UK). Marine Micropaleontology, 52: 29-49. http://dx.doi.org/10.1016/j.marmicro.2004.04.005

Lozar, F. 1992, Biostratigrafia a Nannofossili calcarei nel Lias: risultati di alcune sezioni nel Bacina Lombardo e nel Bacino Delfinese. Palaeopelagos, 2: 89-98.

Lozar, F. 1995, Calcareous nannofossil biostratigraphy of Lower Liassic from western Tethys. Palaeontographia Italica, 82: 91-121.

Mattioli, E. 1993, Quantitative analysis of calcareous nannofossils in the Liassic portion of Pozzale section (Martani Mts., Central Italy): preliminary report. Palaeopelagos, 3: 261-278.
Mattioli, E. 1994, Calcareous nannofossil content of the Toarcian-Aalenian Fiuminata section (Central Apenines, Italy). Palaeopelagos, 4: 175-188

Mattioli, E. 1995, Late Liassic calcareous nannofossils from the Pozzale section (Martani Mts., Central Italy): a quantitative approach to evaluate productivity and diagenesis. Acta Congreso Nanoplancton, p. 83-103.

Mattioli, E. 1996, New Calcareous Nannofossil species from the Early Jurassic of Tethys. Rivista Italiana di Paleontologia e Stratigrafia, 102: 397-412.

Mattioli, E. 1997, Nannoplankton productivity and diagenesis in the rhythmically bedded Toarcian-Aalenian Fiuminata section (Umbria-Marche Apennine, central Italy). Palaeogeography, Palaeoclimatology, Palaeoecology, 130: 113-133. http://dx.doi.org/10.1016/S0031-0182(96)00127-7

Mattioli, E., Erba, E. 1999, Synthesis of calcareous nannofossil events in Tethyan Lower and Middle Jurassic successions. Rivista Italiana de Paleontologia e Stratigrafia, 105 (3): 343-376.

Mattioli, E., Planq, J., Boussaha, M., Duarte, L.V. \& Pittet, B. 2013, Calcareous nannofossil biostratigraphy: new data from the Lower Jurassic of the Lusitanian Basin. Comunicações Geológicas, Especial I, p. 69-76.

Mutterlose, J., 1989. Temperature-controlled migration of calcareous nannofossils in the north-west European Aptian. In: Crux, J.A., van Heck, S.E. (Eds.), Nannofossils and Their Applications: Chichester (Ellis Horwood), p. 122-142.

Mutterlose, J. 1991, Das Verteilungs- und Migrationmuster des kalkigen Nannoplanktons in der borealen Unterkreide (Valangin-Apt) NW Deutschland. Palaeontographica B, 221: 27-152.

Olivero, D. 2008, (with contribution of E. Mattioli), The Aalenian-Bajocian (Middle Jurassic) of the Digne area. In: Guidebook for the Post-Congress Fieldtrip in the Vocontian Basin, SE France (September, 11-13, 2008) 12 $2^{\text {th }}$ Meeting of the International Nannoplankton Association (Lyon, September 7-10, 2008) (Mattioli, E. special ed.).

Olivier, N., Pittet, B. \& Mattioli, E. 2004, Palaeoenvironmental control on sponge-microbialite reefs and contemporaneous deep-shelf marl-limestone deposition (Late Oxfordian, southern Germany). Palaeogeography, Palaeoclimatology, Palaeoecology, 212: 233-263. http://dx.doi.org/10.1016/S0031-0182(04)00313-X

Perilli, N., Fraguas, Á. \& Comas-Rengifo, M.J. 2010, Reproducibility and reliability of the Pliensbachian calcareous nannofossil biohorizons from the BasqueCantabrian Basin (Northern Spain). Geobios, 43: 77-85. http://dx.doi.org/10.1016/j.geobios.2009.06.009

Premoli-Silva, I., Erba, E. \& Tornaghi, M.E. 1989, Paleoenvironmental signals and changes in surface water fertility in mid Cretaceous Corg-rich pelagic facies of the Fucoid Marls (Central Italy). Geobios Mémoire Spécial, 11: 225-236. http://dx.doi.org/10.1016/S0016-6995(89)80059-2

Rai, J., Garg, R. 2007, Early Callovian nannofossils from the Kuldhar section, Jaisalmer, Rajasthan. Current Science, 92: 816-820.

Reale, V., Baldanza, A., Monechi, S. \& Mattioli, E. 1992, Calcareous Nannofossil biostratigraphic events from the EarlyMiddle Jurassic sequences of the Umbria-Marche area (Central Italy). Memorie di Scienze Geologiche Padova, 43: 41-75. 
Reale, V., Monechi, S. 1994, Cyclagelosphaera wiedmannii new species, a marker for the callovian. Journal of Nannofossil Research, 16: 117-119.

Rodd, A.P, Barnard, T. 1974, On Jurassic coccoliths: Stephanolithion, Diadozygus and related genera. Eclogue Geologica Helvetica, 65: 327-342.

Roth, P.H. 1981, Mid-Cretaceous calcareous nannoplankton from the Central Pacific: Implications for paleoceanography. In: Initial Reports of the Deep Sea Drilling Project 62 (Thiede. et al., Eds.). U.S. Government Printing Office, Washington, p. 471-489. http://dx.doi.org/10.2973/dsdp.proc.62.113.1981

Roth, P.H. 1983, Jurassic and Lower Cretaceous calcareous nannofossils in the western North Atlantic (Site 534): biostratigraphy, preservation, and some observations on biogeography and paleoceanography. In: Initial Reports of the Deep Sea Drilling Project 76 (Sheridan, R.E., et al., Eds.). U.S. Government Printing Office, Washington, p. $587-621$.

http://dx.doi.org/10.2973/dsdp.proc.76.125.1983

Roth, P. H., Thierstein, H. 1972, Calcareous nannoplankton; Leg 14 of the Deep Sea Drilling Project. In: Initial Reports of the Deep Sea Drilling Project (Hayes et al., Eds.), Washington, 14: 421-485.

Roth, P.H., Bowdler, J. 1981, Middle Cretaceous nannoplankton biogeography and oceanography of the Atlantic Ocean. In: The Deep Sea Drilling Project: a Decade of Progress (Warme, J.E., Douglas, R.G., Winterer, E.L., Eds.). SEPM Society for Sedimentary Geology, Special Publications, 32: 517-546.

http://dx.doi.org/10.2110/pec.81.32.0517

Roth, P.H., Krumbach, K.R. 1986, Middle Cretaceous calcareous nannofossil biogeography and preservation in the Atlantic and Indian oceans: implications for paleoceanography. Marine Micropaleontology, 10: 235-266. http://dx.doi.org/10.1016/0377-8398(86)90031-9

Thierry, J. 2000, Middle Callovian (157-155 Ma). In: Atlas Peri-Tethys Palaeogeographical Maps (Dercourt, et al., Eds.), CCGM/CGMW, Paris, p. 71-97.

Thierstein, H.R. 1980, Selective dissolution of Late Cretaceous and Earliest Tertiary calcareous nannofossils: experimental evidence. Cretaceous Research, 2: 165-176. http://dx.doi.org/10.1016/0195-6671(80)90023-3

Thierstein, H.R. 1981, Late Cretaceous nannoplankton and the change at the Cretaceous-Tertiary boundary. SEPM Society for Sedimentary Geology, Special Publications, 32: 355-394.
Thomsen, E. 1989, Seasonal variation in boreal Early Cretaceous calcareous nannofossils, Marine Micropaleontology, 15: 123-152. http://dx.doi.org/10.1016/0377-8398(89)90008-X

Tremolada, F., Erba, E., van de Schootbrugge, B. \& Mattioli, E. 2006, Calcareous nannofossil changes during the late Callovian-early Oxfordian cooling phase. Marine Micropaleontology, 59: 197-209.

http://dx.doi.org/10.1016/j.marmicro.2006.02.007

Sciunnach, D., Erba, E. 1994, Il "selcifero" di Lingornetto (Canton Ticino). Bollettino della Società ticinese di Scienze Naturali, 82: 65-110.

Seyed-Emami, K., Schairer, G. \& Aghanabati, S.A. 1997, Ammoniten aus der Baghamshah Formation (Callov, Mittlerer Jura), NW Tabas (Zentraliran). Mitteilungen der Bayerischen Staatssammlung fur Palaeontologie und historische Geologie, 37: 24-40.

Seyed-Emami, K., Schairer, G., Aghanabati, S.A., Fürsich, F.T., Senowbari-Daryan, B. \& Majidifard, M.R. 1998, Cadomites aus der unteren Baghamshah-Formation (Oberbathon, Mittlerer Jura) SW Tabas (Zentraliran). Mitteilungen der Bayerischen Staatssammlung für Paläontologie und Historische Geologie, 38: 111-119.

Seyed-Emami, K., Schairer, G, Fürsich, F.T.,Wilmsen, M. \& Majidifard, M.R. 2002, Reineckeiidae (Ammonoidea) from the Callovian (Middle Jurassic) of the Shotori Range (East-Central Iran). Neues Jahrbuch für Geologie und Paläontologie, Monatshefte, 3: 184-192.

Seyed-Emami, K., Fürsich, F.T., Wilmsen, M., Majidifard, M.R. \& Shekarifard, A. 2008, Lower and Middle Jurassic ammonoids of the Shemshak Group in Alborz, Iran and their palaeobiogeographical and biostratigraphical importance. Acta Palaeontologica Polonica, 53: 237-260. http://dx.doi.org/10.4202/app.2008.0206

Stöcklin, J. 1961, Lagoonal formations and salt domes in East Iran. Bulletin of the Iranian Petroleum Institute, 3: 29-46.

Stöcklin, J., Eftekhar-Nezhad, J. \& Hushmandzadeh, A. 1965, Geology of the Shotori Range (Tabas Area, East Iran). Geological Survey of Iran, Report 3.

Williams, J.R., Bralower, T.J. 1995, Nannofossil assemblages, fine fraction isotopes, and the paleoceanography of the Valanginian-Barremian (Early Cretaceous) North Sea Basin. Paleoceanography, 10: 815-839. http://dx.doi.org/10.1029/95PA00977

Young, J.R., Teale, T. \& Bown, P.R. 1986, Revision of the Stratigraphy of the Longobucco group (Liassic, southern Italy), based on new data from nannofossils and ammonites. Eclogue Geologica Helvetica, 79: 117-135. 
PLATE I. Calcareous nannofossils from the Baghamshah Formation (Iran). The pictures are captured in: XPL - cross-polarized light, $\mathrm{BF}$ - bright field, GP- gypsum plate. Scale bar on all the figures is of $2 \mu \mathrm{m}$.

Fig. 1. - Watznaueria barnesiae (Black in Black and Barnes, 1959) Perch-Nielsen, 1968 (Sample B1, XPL);

Figs. 2 - 3. Lotharingius sp. (Sample B10, same specimen, XPL and GP);

Fig. 4. Lotharingius cf. velatus Bown and Cooper, 1989 (Sample B3, XPL);

Fig. 5. - Watznaueria sp. (Sample B10, XPL);

Fig. 6. - Watznaueria britannica (Stradner, 1963) Reinhardt, 1964 (Sample B3, XPL);

Fig. 7. - Watznaueria fossacincta (Black, 1971) Bown in Bown and Cooper, 1989 (Sample B3, XPL);

Fig. 8. - Watznaueria sp. (Sample B7, XPL);

Figs. 9 - 10. Watznaueria barnesiae (Black in Black and Barnes, 1959) Perch-Nielsen, 1968 (Sample B3, same specimen, XPL and BF);

Figs. 11 - 12. Watznaueria barnesiae (Black in Black and Barnes, 1959) Perch-Nielsen, 1968 (Sample B10, same specimen, XPL and BF);

Figs. 13 - 14. Watznaueria barnesiae (Black in Black and Barnes, 1959) Perch-Nielsen, 1968 (Sample B5, same specimen, XPL and BF);

Fig. 15. - Watznaueria cf. manivitiae Bukry, 1973 (Sample B10, XPL);

Fig. 16. - Watznaueria cf. manivitiae Bukry, 1973 (Sample B3, XPL);

Figs. 17 - 18. Watznaueria communis Reinhardt, 1964 (Sample B1, same specimen, BF and XPL);

Fig. 19. - Watznaueria cf. manivitiae Bukry, 1973 (Sample B3, XPL);

Fig. 20. - Watznaueria britannica (Stradner, 1963) Reinhardt, 1964 (Sample B9, XPL);

Figs. 21 - 22 - 23. Watznaueria fossacincta (Black, 1971) Bown in Bown and Cooper, 1989 (Sample B5, same specimen, BF, XPL and GP);

Fig. 24. - Watznaueria barnesiae (Black in Black and Barnes, 1959) Perch-Nielsen, 1968 (Sample B10, XPL);

Fig. 25. - Watznaueria britannica (Stradner, 1963) Reinhardt, 1964 (Sample B1, XPL);

Figs. 26 - 27. Watznaueria cf. ovata Bukry, 1969 (Sample B10, same specimen, BF and XPL);

Figs. 28 - 29. Watznaueria britannica (Stradner, 1963) Reinhardt, 1964 (Sample B4, same specimen, BF and XPL);

Figs. 30 - 31. Watznaueria britannica (Stradner, 1963) Reinhardt, 1964 (Sample B3, same specimen, XPL and BF). 
PLATE I
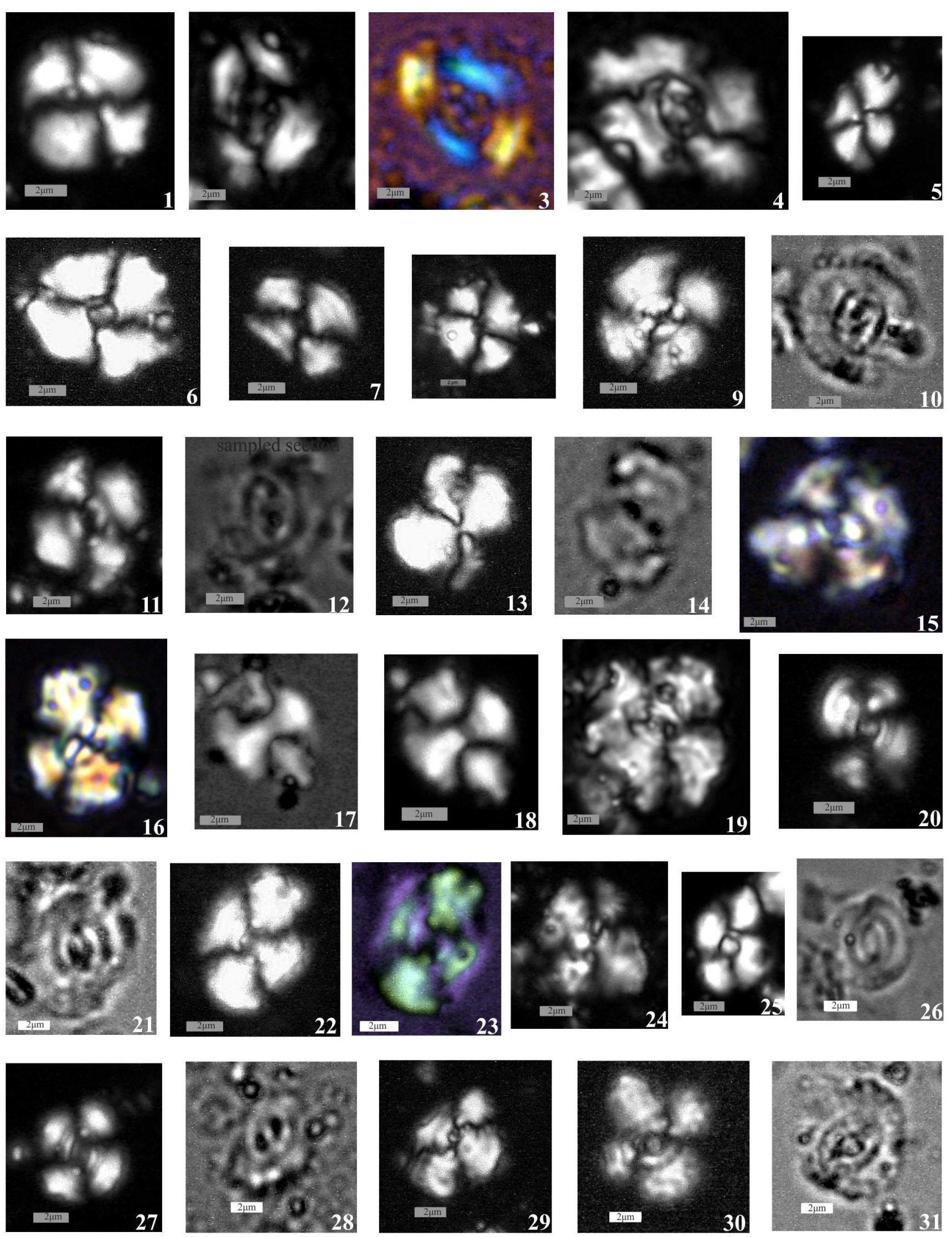
PLATE 2. Ammonites from the Baghamshah Formation (Iran). Scale bar on all the figures is of $1 \mathrm{~cm}$.

Fig. 1. - Reineckeia sp. A (lateral view);

Fig. 2. - Rehmannia sp. A (lateral view);

Fig. 3. - Choffatia sp. (lateral view);

Figs. 4 - 5. Rehmannia sp. B (microconch?, same specimen, lateral and ventral views);

Figs. 6 - 7. Reineckeia sp. A (same specimen, lateral and ventral views);

Figs. 8 - 9. Reineckeia sp. B (same specimen, lateral and ventral views). 
PLATE II

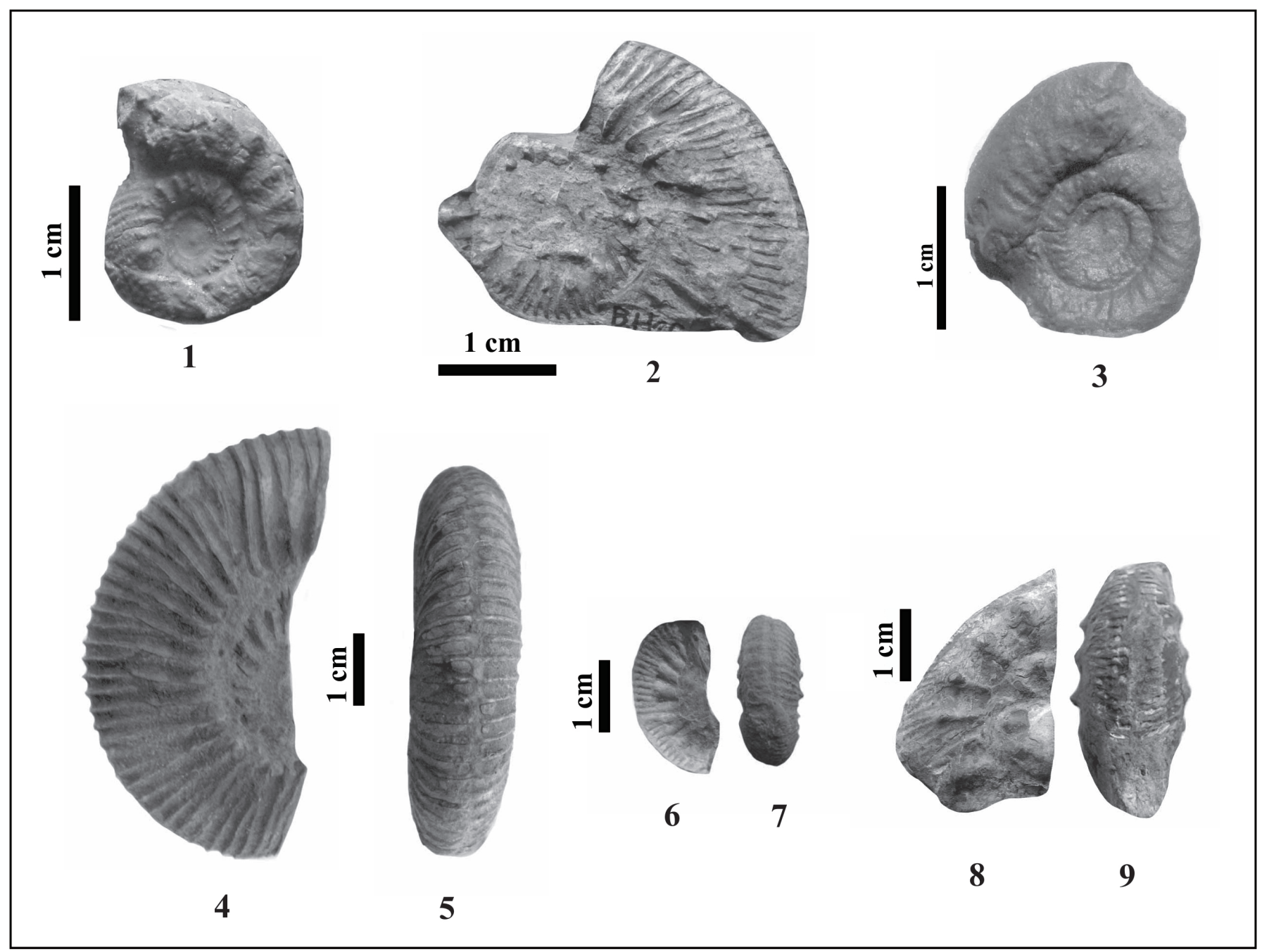


Appendix 1. List of calcareous nannofossil species identified in the studied outcrop (Baghamshah Formation, Iran), arranged in alphabetical order.

C

Calculites obscurus (Deflandre, 1959) Prins and Sissingh in Sissingh, 1977

Coccolithus foraminis Bown, 2005

Coccolithus pelagicus (Wallich 1877) Schiller, 1930

Cribrosphaerella ehrenbergii (Arkhangelsky, 1912) Deflandre in Piveteau, 1952

Cyclagelosphaera sp. Noël, 1965

Cyclagelosphaera cf. wiedmannii Reale and Monechi, 1994

\section{D}

Discoaster sp. Tan, $1927 \mathrm{~b}$

$\mathbf{L}$

Lotharingius cf. velatus Bown and Cooper, 1989

Lotharingius sp. Noël, 1973

$\mathbf{R}$

Reticulofenestra sp. Hay, Mohler and Wade, 1966

$\mathbf{S}$

Sphenolithus sp. Deflandre in Grassé, 1952

W

Watznaueria barnesiae (Black in Black and Barnes, 1959) Perch-Nielsen, 1968

Watznaueria britannica (Stradner, 1963) Reinhardt, 1964

Watznaueria communis Reinhardt, 1964

Watznaueria fossacincta (Black, 1971) Bown in Bown and Cooper, 1989

Watznaueria cf. manivitiae Bukry, 1973

Watznaueria cf. ovata Bukry, 1969

Watznaueria sp. Reinhardt, 1964 